\title{
Effects of Handling and Storage Systems on the Lipid Oxidation and Fatty Acid Level of the African Snakehead Fish (Parachanna Obscura)
}

\author{
Olutimehin Isaac. $\mathrm{O}^{1}$, Adejuyigbe Ireoluwa $\mathrm{J}^{2}$. and Fasuhanmi Oluwagbemiga $\mathrm{S}^{3}$. \\ ${ }^{1,2}$. Joseph Ayo Babalola University, P.M.B.5006, Ilesha, Osun state. \\ ${ }^{3}$ Federal University of Technology Akure, P.M.B 704, Akure, Ondo state
}

\begin{abstract}
This research evaluated the effect of handling and storage methods on the nutritional qualities of the Snakehead fish (Parachanna obscura). $1 \mathrm{~kg}$ of fresh fish samples acquired from Eleyele reservoir, Ibadan, Nigeria was divided into three equal parts, fresh frozen part at below $0^{\circ} \mathrm{C}$, oven dried part at a temperature of $105^{\circ} \mathrm{C}$ at $5 \%$ moisture, and coal smoking in a kiln initially at $65^{\circ} \mathrm{C}$ till $110^{\circ} \mathrm{C}$ for 24 hours. The samples were subjected to drying and stored in polythene material at room temperature. The samples were analyzed over a period of six weeks for Protein, lipid, carbohydrate, ash and spoilage parameters (Lipid Peroxide, Total Volatile Base-Nitrogen, Trimethylamine acid and Free Fatty Acids) using standard methods. Proximate analysis showed that Fat ranged from 7.89-26.40\%, Protein from 13.73-33.38\%, ash content from 8.14-14.20\% and the Carbohydrate content from 5.43$25.67 \%$, moisture content from 5.44-64.53\%. FFA from 14.42-33.62mg/KOH/g, cholesterol level from $11.00-57.00 \%$, lipid peroxidation (TBA) from $0.65-8.06 \mathrm{mg} / \mathrm{MDA}$, TVB-N from $31.21-254.85 \mathrm{mg} / 100 \mathrm{~g}$, and TMA from $0.09-1.84 \mathrm{mg} / 100 \mathrm{~g}$. There was significant reduction in the proximate characteristics in relation to time, and there were significant differences due to the treatments received. There were significant differences in the spoilage parameters in relation to treatment and time. Spoilage parameters increased during the six weeks storage period at $(\mathrm{P}<0.05)$ However, frozen Parachanna obscura stored better and retained its freshness most in the period of 6 weeks. Research finding revealed that smoking is the best method for preserving Parachanna obscura followed by oven drying only if oven post- processing rancidity reduction can be further researched.
\end{abstract}

Keywords: Handling and storage systems, lipid oxidation, African snakehead fish.

\section{INTRODUCTION}

In low-income countries especially Africa, staple foods such as rice, wheat, maize, and cassava make up the bulk of the food consumed by the people. However, these foods lack essential nutrients, (essential amino, fatty acids and micronutrients) which can be supplied by fish because they contain very light connective tissue (Eyo 2001). Fish is said to be an important aspect of the human diet and known to be rich in protein and essential fatty acids which are Omega 6 and Omega 3 fatty acids, and low in crude fiber which makes it easy to digest when compared to some other meat sources (Health Canada, 2011)

Studies showed that reduction in Omega 3 fatty acids reduces the shelf life of fishes thereby enhancing faster deterioration rate of fishes when compared to other sources of meat (Simopoulos, 2002). Lack of adequate handling, storage and processing facilities has thus hastened the rate of deterioration and cause fish spoilage (Adeyeye, 2016). Moreover, studies have shown that $30-50 \%$ of fish harvested in Nigeria end up being wasted due to the problem of poor handling and transportation (Adeyeye, 2016).

Parachanna obscura, also known as the obscure snakehead is a highly commercial, medium-sized high protein and lipid value carnivorous fish that possesses an elongated shape tapered on both ends. Due to its high market demands, it has become overfished, and an endangered specie despite its high protein profile (Oyekanmi and Olutimehin, 2019). However, it has been proven to be culturable and contend competently with other conventional fishes in Nigeria. (kigbu et al., 2014). It has also found to contribute highly to children nutrition and growth due to its protein level (Ama -abasi, 2013), which call for deeper studies on its handling and processing to further exploit its potentials and reduce its physical and nutritional wastages. Moreover, there are limited information on standard handling and processing methods of Parachanna obscura, leading to mass wastage despite the low protein nutrition status in Nigeria. Most times, fishes that are bought frozen mostly defreeze before it is being transported to the consumer's house, causing high deterioration level at points unknown in snakehead fish since rate of deterioration differs among fish species.( F.A.O.,1995). Hence, there is a need to look at variations in the chemical content degradation of its flesh using the most common day to day Nigerian market women's processing and handling methods with a view to procure better preservation techniques from the result observed. In addition, this research aims to proffer solutions which will reduce the rate of essential nutrient degradation from catch point to fork or table point.

There are many processes involved in food spoilage from rigomortis to chemical variations which alter fishes' nutritional balance. Trimethylamine acid (TMA) is an example and has a strong "Fishy" odor in low concentrations and a rotten egg smell at higher concentrations which dictates the presence of ammonia gas. TMA is a Nitrogenous base which is a product of decomposition of plants and animals. In this context, it is a product of decomposition of fish. (Raes, 2015).In humans, 
it is produced by the gut micro biota from nutrients. It assists in decomposition of food in the gut (Raes, 2015).

Total Volatile Base Nitrogen (TVBN) is another chemical components also referred to as the index of freshness. The higher the concentration of TVB-N the lower the level of freshness and higher the rate of deterioration. (Acronymn finder, 2018). Both TMA and TVB-N are non-sensory chemical components of fish that reveals the rate of deterioration of fish and any other meat.

Lipid oxidation is the oxidative reduction of the quality of lipids. In this process, free radicals steal electrons from the lipids in cell membranes, leading to damages in cells.

This process most often affects polyunsaturated fatty acids because of their double bonds between $\mathrm{CH}_{2}$ that contains reactive hydrogen atoms. The chemical products of this process are called lipid peroxides or lipid oxidation products (LOPs). Thiobarbituric acid (TBARS) is a major product of lipid peroxidation. However, Free Fatty acids are by-products of the metabolism of fat in adipose tissues.

\section{Sample Collection}

\section{MATERIALS AND METHODS}

One kilogram of Fresh Samples of Parachanna obscura was acquired from Eleyele Reservoir in Oyo state with the help of local fishermen who used drag net to acquire fishes from the Eleyele Reservoir. The fishes were transported to Federal University of Technology Akure inside a cooler with Ice blocks.

Sample Processing and Storage

The samples were divided into three equal parts of $0.33 \mathrm{~kg}$ each. One of the subsamples was taken back into the freezer to be cooled at a temperature below $0^{\circ} \mathrm{C}$ for a period of ten to twelve hours per day.

The second subsample was subjected to smoking in a smoking kiln. This was done using the smoking Kiln in The Federal University of Technology, Akure, (FUTA) teaching and research farm. The fishes were smoke dried for a period of 24 hours till it attained the temperature of $110^{\circ} \mathrm{C}$. It was then removed from the smoking kiln after 24 hours. The subsample was blended to flour with the use of a Kenwood blender. The subsample was packed in Nylon and labeled. It was kept in a rubber take away and stored in the lab without freezing.

The third subsample was subjected to oven drying in an Ignis gas Oven at $105^{\circ} \mathrm{C}$. This was done for a period of 3 hours. This sample was also grounded into powdery form and then stored in Nylon. It was also kept safely in the laboratory without refrigeration or freezing, mimicking the processing methods practiced by Nigerian fish traders. All samples were subjected to proximate analysis for a period of 6 weeks and data were collected every 3 weeks to note the changes in nutritional values with time.
Figure 1: Map of Nigeria Showing Eleyele reservoir

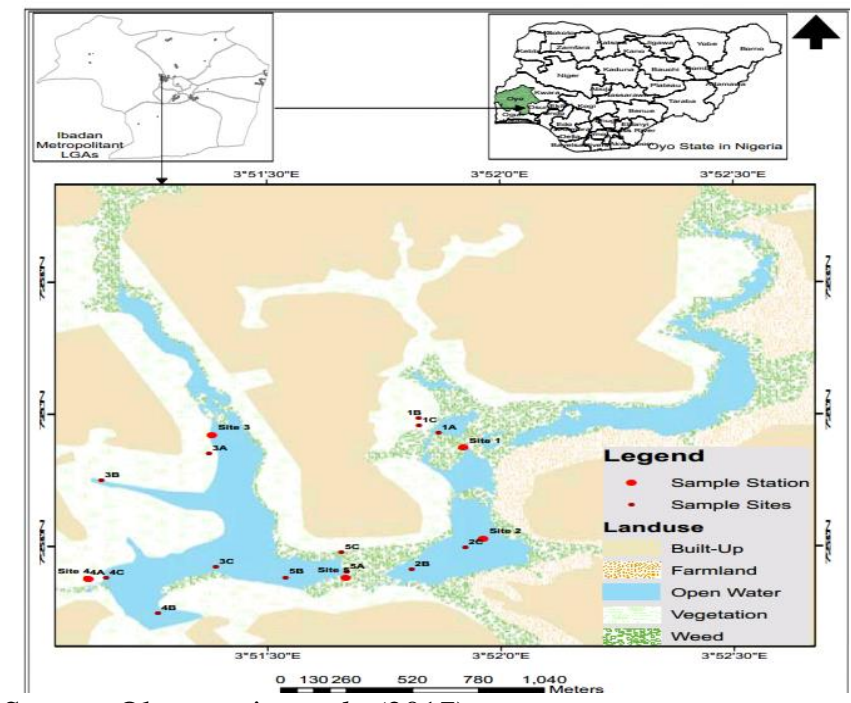

Source: Olanrewaju et al., (2017)

\section{PROXIMATE ANALYSIS \\ AOAC method (2000)}

1. The proximate analysis was determined by the method described by Association of Official Analytical Chemist (2006).

2. Free Fatty Acid Analysis

Free fatty acid in fish was estimated by dissolving the distilled sample extract in $50 \mathrm{ml}$ of neutral solvent in a $250 \mathrm{ml}$ conical flask, adding a few drops of phenolphthalein and titrating it against Potassium hydroxide and shaken till a pink colour appeared.

3. Cholesterol

The cholesterol is determined using spectrophotometry method as described by Chod-Pod (July 2013) with the aid of a cholesterol pack. The samples and standard were well mixed with working reagent and let to stand for ten minutes at room temperature $\left(20-25^{\circ} \mathrm{C}\right)$ for the colour to develop and the wavelength was read at $546 \mathrm{~nm}$ or $505 \mathrm{~nm}$.

4. Trimethylamine acid determination (TMA)

Using the modified method of Gibson (1972) and Hasegawa (1987), 10g of each subsample was added into $30 \mathrm{ml}$ of $5 \%$ TCA for extraction for some time with $4 \mathrm{ml}$ of the extract drained into test tubes and $10 \mathrm{ml}$ of Toluene added to the test tube. $1 \mathrm{ml}$ of $3.7 \%$ formaldehyde solution was added and allowed to stand for 5 minutes. $3 \mathrm{ml}$ of $25 \%$ $\mathrm{KOH}$ was also added before sealing the test tube. $7 \mathrm{ml}$ of the Toluene layer was the upper layer of the sediment solution. This layer was removed and dried with $0.5 \mathrm{~g}$ anhydrous $\mathrm{Na}_{2} \mathrm{SO}_{4} .5 \mathrm{ml}$ of the toluene was added to $1.25 \mathrm{ml}$ of $0.02 \%$ picric acid to determine the Trimethylamine content of the sample.

The mixture was then taken into a standard spectrophotometer (721G Visible Spectrophotometer) and measurement done at $415 \mathrm{~nm}$.

5. Total Volatile base Nitrogen (TVBN) Determination

The TVB-N was determined by slightly modifying Ocial method (Ociad 1995, Jindasa 2014). 
Ten grams of each subsample was taken with $20 \mathrm{ml}$ of $7.5 \%$ TCA, It was filtered and $10 \mathrm{ml}$ of the extract was pipetted into distillation tube and placed into a distillation flask. $10 \mathrm{ml}$ of $10 \% \mathrm{NAOH}$ and $10 \mathrm{ml}$ of distilled water were added and the distillate was collected in a flask containing $25 \mathrm{ml} \mathrm{4 \%} \mathrm{Boric} \mathrm{acid} \mathrm{and} \mathrm{a} \mathrm{few} \mathrm{drops} \mathrm{of} \mathrm{mixed} \mathrm{indicator}$ (Methyl red and methyl blue 2:1). After $10 \mathrm{ml}$ of distillate was collected, it was then titrated against $0.025 \mathrm{~N} \mathrm{H}_{2} \mathrm{SO}_{4}$ to the end point shown with a pink colour.

TVB-N $(\mathrm{mg} / 100 \mathrm{~g})=14 \mathrm{mg} / \mathrm{mole} \mathrm{X}$ a X b X300/25ml $\mathrm{a}=\mathrm{ml}$ of $\mathrm{H}_{2} \mathrm{SO}_{4}$ - titrated, $\mathrm{b}=$ Normality of $\mathrm{H}_{2} \mathrm{SO}_{4}$

6. Lipid oxidation determination (TBA)

Lipid oxidation was assessed in duplicate of each subsample using the 2-thiobarbituric acid reactive substances (TBARS) method of Lopez et al (2005). Ten grams of each sample was mixed with $50 \mathrm{ml}$ distilled water then transferred to a distillation tube. The cup used for mixing was rinsed with an additional $47.5 \mathrm{ml}$ of distilled water. This was then added to a distillation tube containing $2.5 \mathrm{ml} 4 \mathrm{~N} \mathrm{HCL}$ (taken with a micropipette) and a few drops of antifoam agent. $5 \mathrm{ml}$ of $0.02 \mathrm{M}$ 2-TBARS acid in $90 \%$ acetic acid glacial (a TBA reagent) was added to a vial containing $5 \mathrm{ml}$ of distillate and mixed well. The vials were capped and heated in boiling water for 30 minutes and cooled to room temperature. The absorbance was measured at $532 \mathrm{~nm}$ using a Spectrophotometer (721G Visible Spectrophotometer).

Spoilage Parameters Result

\section{RESULTS AND DISCUSSIONS}

1. Changes in quality indices of fresh frozen fish (FFS)

The Lipid peroxide (TBA) (mg/MDA) of fresh fish ranged between from 1.19 (Wk 0) to 3.61 (Wk 6), this increased steadily during storage period at a significant rate $(\mathrm{p}<0.05)$. TBA significantly increased between $0-6$ weeks. In general, FFA significantly increased during the storage periods $(0-6 \mathrm{Wks})$. The free fatty acid (FFA) was 15.4 $\mathrm{mg} / \mathrm{KOH} / \mathrm{g}(\mathrm{Wk} 0)$ and increased significantly $(\mathrm{p}<0.05)$ during storage to $21.32 \mathrm{mg} / \mathrm{KOH} / \mathrm{g}$ (Wk 6). Total volatile base nitrogen (TVB-N) (mg/100 g) of Wk 0 was 31.21. TVB-N increased significantly as storage progressed from 31.21 to 254.85 (6th $\mathrm{Wk}$ ). TBA values (mg $\mathrm{MDA} / \mathrm{g}$ ), significantly increased $(\mathrm{p}<0.05)$ during storage periods, from $1.19(0 \mathrm{Wk})$ to 2.53 (6th Wk). Cholesterol values significantly decreased during storage in the range of 27.04 to 11.00 . Trimethylamine value increased significantly during storage in the range of 0.09 to 0,92 .

2. Quality indices changes of Kiln Smoked Sample stored under room temperature (KSS)

The TMA (mg/MDA) of Kiln smoked Sample (Wk 0), increased steadily during storage from 0.07 to $1.83 \mathrm{meq}$ O2/kg (6th Wks.). FFA (\%) of Wk 0 increased during storage from 0.43 to 1.42 (6th $\mathrm{Wk}$ ). TVN values (mg $\mathrm{N} / 100 \mathrm{~g}$ ) significantly $(\mathrm{p}<0.05)$ increased from 16.79 (Wk $0)$ to 33.62 (Wk 6). TBA values ranged from 0.65 (Wk 0 ) to 3.61 (Wk 6).

TVN (mg N/100g) increased significantly $(\mathrm{p}<0.05)$ as storage proceeded from $44.05 \%$ to $254.85 \%$ (6th Wk). TBA (mg/MDA) significantly increased during storage from $0.25 \mathrm{mg} / \mathrm{g}$ (Wk 0) to $1.42 \mathrm{mg} / \mathrm{g}$ (6th Wk).

3. Quality indices changes of Oven Dried Sample (ODS)

The TMA (mg/MDA) of Kiln smoked Sample (Wk 0), increased steadily during storage from 0.09 to 1.84 $\mathrm{mg} / 100 \mathrm{~g}$ (6th Wk). FFA (\%) of Wk 0 increased during storage from 16.80 to 25.43 (6th Wk). TVN values (mg $\mathrm{N} / 100 \mathrm{~g})$ significantly $(\mathrm{p}<0.05)$ increased from 31.79 (Wk $0)$ to 211.64 (Wk 6).TBA values (mg/MDA) significantly increased during storage from $5.16 \mathrm{mg} / \mathrm{g}$ (Wk 0) to 8.06 mg/MDA (6th Wk)

Table 1: Spoilage Parameters value with time

\begin{tabular}{|c|c|c|c|c|c|}
\hline $\begin{array}{l}\text { SAMPLES/ } \\
\text { Time } \\
\text { WEEK } 0\end{array}$ & FFA (mg/KOH/g) & $\begin{array}{l}\text { CHOLESTEROL } \\
\text { (mg Cholest./dl) }\end{array}$ & TBA (mg/MDA) & TVB-N (mg/100g) & TMA (mg/100g) \\
\hline FFS & $14.42 \pm 0.233^{b}$ & $27.04 \pm 1.562^{b}$ & $1.19 \pm 0.039^{\mathrm{b}}$ & $31.21 \pm 0.183^{\circ}$ & $0.09 \pm 0.007^{\mathrm{ab}}$ \\
\hline ODS & $16.80 \pm 0.042^{\mathrm{a}}$ & $57.00 \pm 4.24^{\mathrm{a}}$ & $5.16 \pm 0.084^{\mathrm{a}}$ & $31.79 \pm 0.176^{b}$ & $0.12 \pm 0.021^{\mathrm{a}}$ \\
\hline KSS & $16.79 \pm 0.049^{a}$ & $56.50 \pm 2.12^{\mathrm{a}}$ & $0.65 \pm 0.007^{\circ}$ & $44.05 \pm 0.070^{\mathrm{a}}$ & $0.07 \pm 0.007^{\mathrm{b}}$ \\
\hline \multicolumn{6}{|l|}{ WEEK 3} \\
\hline FFS & $16.70 \pm 0.183^{\circ}$ & $16.60 \pm 0.848^{\circ}$ & $1.65 \pm 0.064^{\mathrm{b}}$ & $40.09 \pm 0.318^{\mathrm{a}}$ & $0.58 \pm 0.028^{b}$ \\
\hline ODS & $17.91 \pm 0.049^{\mathrm{b}}$ & $41.00 \pm 1.414^{\mathrm{a}}$ & $7.17 \pm 0.068^{\mathrm{a}}$ & $35.57 \pm 0.183^{\circ}$ & $1.15 \pm 0.077^{\mathrm{a}}$ \\
\hline KSS & $29.25 \pm 0.106^{\mathrm{a}}$ & $35.00 \pm 1.414^{\mathrm{b}}$ & $1.26 \pm 0.031^{\circ}$ & $37.79 \pm 0.155^{b}$ & $1.10 \pm 0016^{\mathrm{a}}$ \\
\hline \multicolumn{6}{|l|}{ WEEK 6} \\
\hline FFS & $21.32 \pm 0.021^{\mathrm{a}}$ & $11.00 \pm 1.414^{\mathrm{a}}$ & $2.53 \pm 0.111^{\circ}$ & $99.39 \pm 0.212^{\circ}$ & $0.92 \pm 0.007^{b}$ \\
\hline ODS & $25.43 \pm 0.516^{b}$ & $26.60 \pm 0.654^{b}$ & $8.06 \pm 0.224^{\mathrm{a}}$ & $211.64 \pm 0.544^{b}$ & $1.84 \pm 0.056^{\mathrm{b}}$ \\
\hline KSS & $33.62 \pm 0.056^{\circ}$ & $29.08 \pm 2.223^{\mathrm{a}}$ & $3.61 \pm 0.085^{\mathrm{b}}$ & $254.85 \pm 0.728^{\mathrm{a}}$ & $1.83 \pm 0.070^{\mathrm{a}}$ \\
\hline
\end{tabular}

FFS= Freshly Frozen Sample, ODS= Oven Dried Samples, KSS= Kiln Smoked Samples. *SD= Standard Deviation *Mean \pm SD are values of triplicate determination. ${ }^{*} \mathrm{SD}$ with different superscripts in the same column for each parameter are significantly $(\mathrm{P}<0.05)$ different 


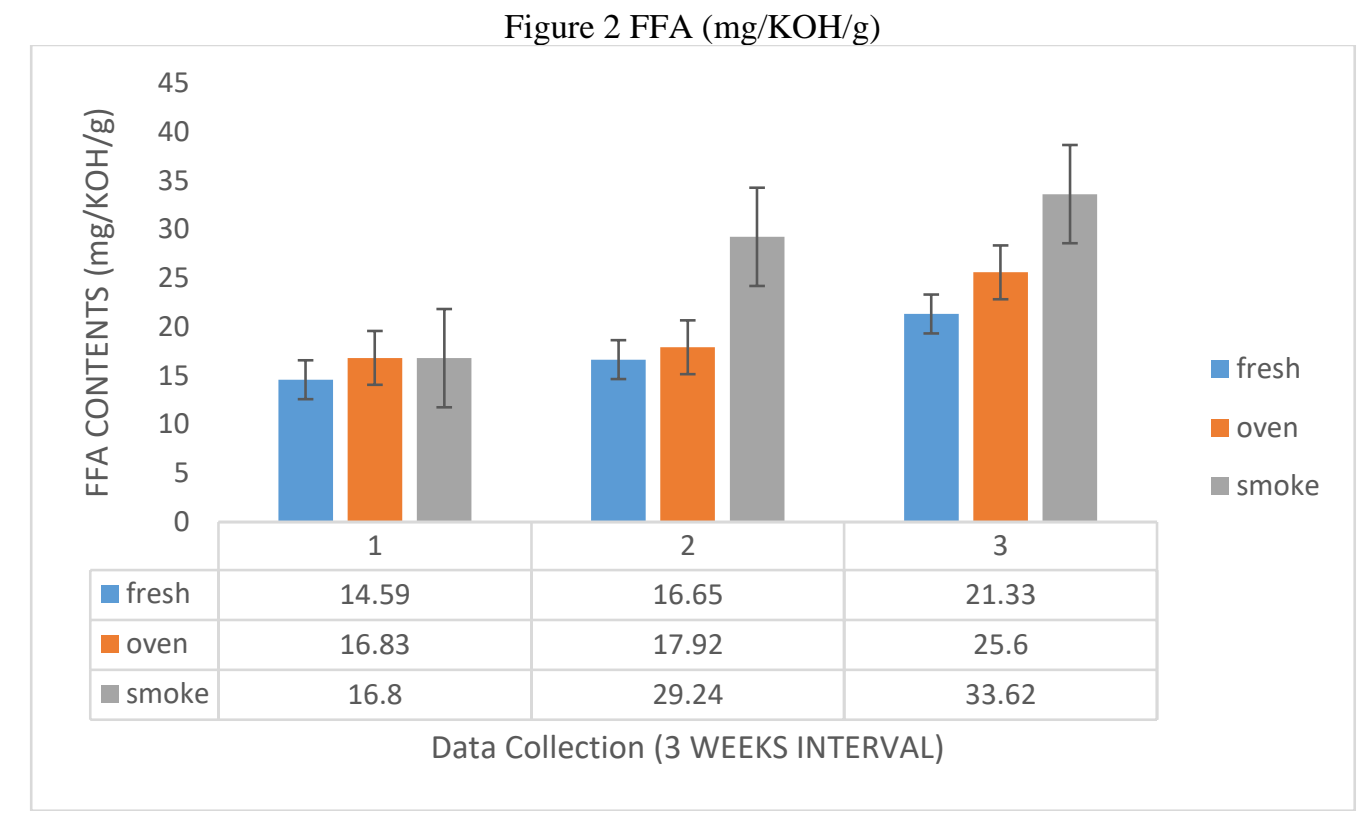

From Figure 2, the level of the free fatty acids was close initially when exposed to all the three treatments. But, there were slight improvements in the free fatty acid content of African snakehead on the first week. This means that oven drying has a way of making the free fatty acid level to be more concentrated in the fish. This means oven drying supports the metabolism of snakehead's adipose tissues.

As time goes by after the $3^{\text {rd }}$ week, there is more metabolism of adipose tissues in smoking hereby surpassing that of oven drying. Continuous increase was noticed till the $6^{\text {th }}$ week.

This shows that in terms of free fatty acid composition, smoking has the best effect on the long run. On the short run, oven drying has a little advantage over smoking. A compound present in the smoke of the smoking kiln encourages the metabolism of adipose tissues to give us these free fatty acids with time.

Figure 3 Cholesterol (mg Cholest/dl)

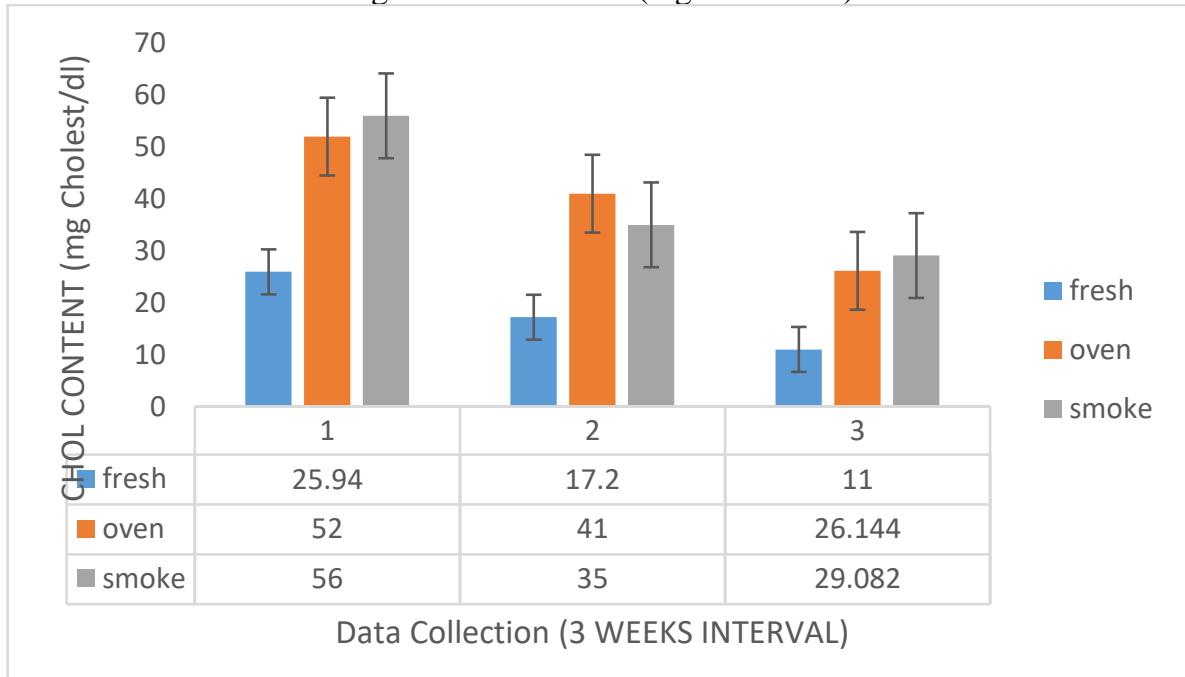

In the figure above, the fresh Parachanna contained higher cholesterol which decreases with time. When compared, the freshly frozen fish contain less cholesterol compared to the two other treatments. This is an indication that the drying procedure has made the cholesterol content to be more concentrate in the fish sample. From the chart above, we can deduce that smoking helps in improving the cholesterol composition. Fish cholesterol is a good form of cholesterol. So in terms of the drastic reduction in cholesterol level, it simply shows that there is a decomposition of the cholesterol. This simply means the cholesterol is being converted to another compound which is unknown. 
Figure 4 TVB-N (mg/100g)

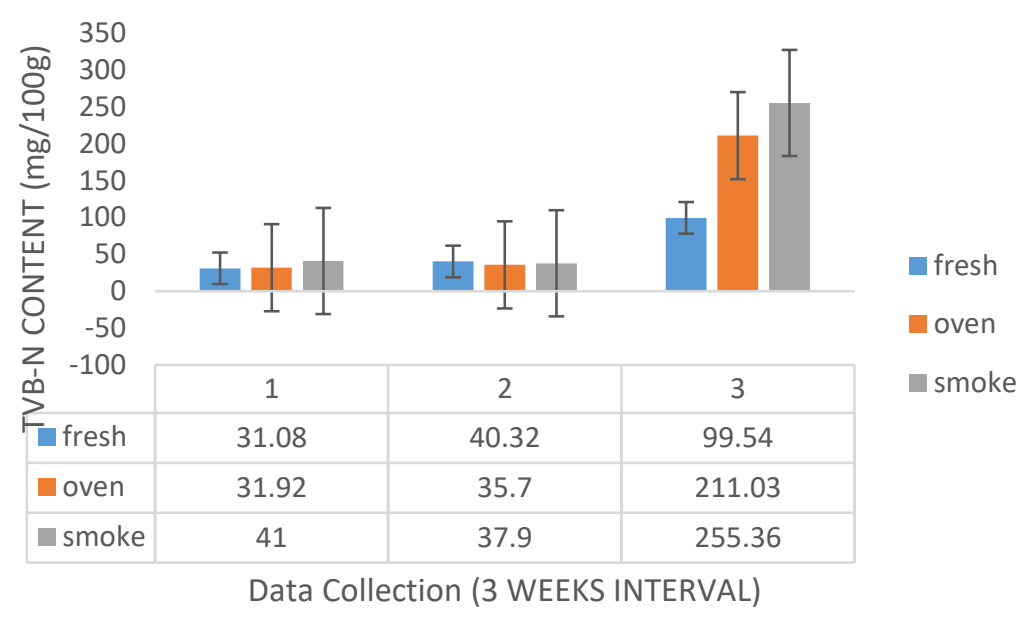

In the chart above, the total volatile base nitrogen (TVBN) was low, which indicates that the subsamples were still fresh, but there was a slight increase in the TVB-N of the smoked snakehead fish, indicating reduction in the index of freshness of the fish with the highest value for smoking at the $6^{\text {th }}$ week.

Figure 5 TBA (mg/MDA)

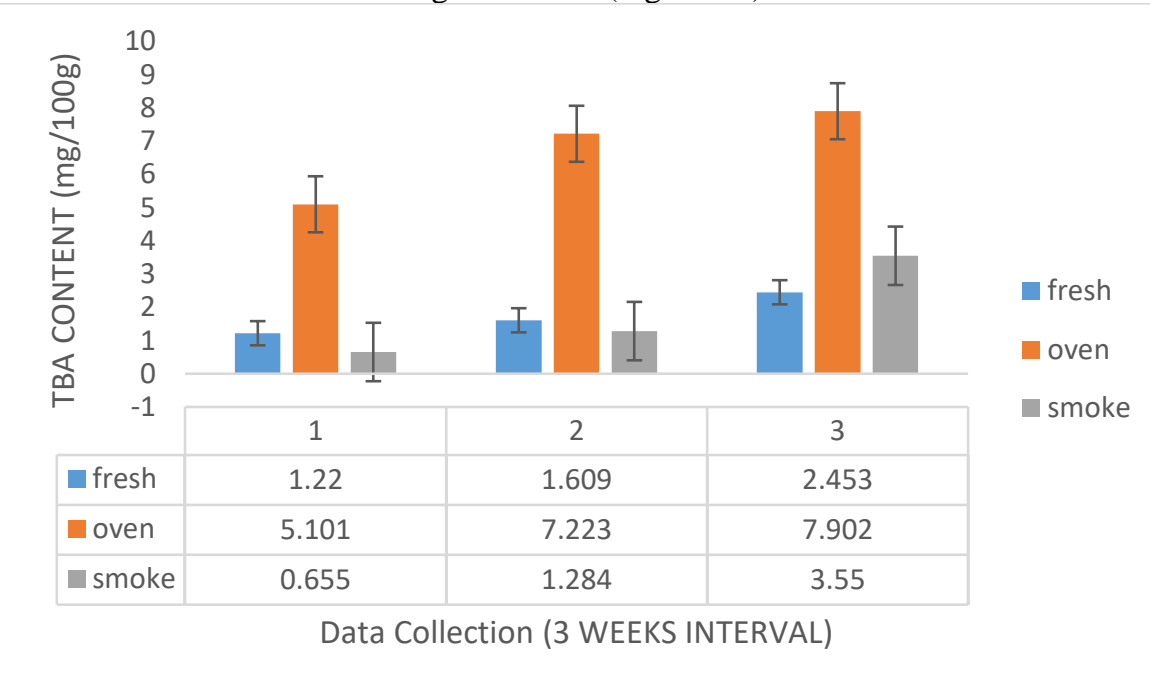

Lipid content in oven dried fish exhibited high oxidation in Parachanna obscura, but minimized in smoking and freezing. With time, the TBA content of each process increases. Higher values were recorded in smoking that frozen sample (fresh) with time due to its exposure to light. Indicating exposure of the fish lipid to oxidation compared to that of kiln smoking and freshly frozen.

Figure 6 TMA (mg/100g)

\begin{tabular}{|c|c|c|c|c|c|}
\hline & 2.5 & & & & \\
\hline की & 2 & & & & \\
\hline 이 & 1.5 & & & & \\
\hline ख్ & 1 & & & & \\
\hline है & 0.5 & & & & FRESH \\
\hline$\sum_{u}$ & 0 & 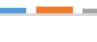 & & & \\
\hline 巨 & -0.5 & & & & OVEN \\
\hline U & -1 & 1 & 2 & 3 & - SMOKE \\
\hline$\sum$ & aRESH & 0.089 & 0.6 & 0.92 & \\
\hline & OVEN & 0.11 & 1.21 & 1.88 & \\
\hline & SMOKE & Daஸ̈ & (B.1/) & RV.AL) & \\
\hline
\end{tabular}


From the figure above, the Trimethylamine content which is a product of decomposition increases with time with differences in treatments. Oven dried samples decomposed faster than smoked samples and frozen samples.

Micro-organisms that cause decomposition operate more under room temperature but cannot thrive well in low temperature (Gornik et al., 2011). The oven dried and kiln smoked samples were stored under room temperature which resulted in quicker rate of deterioration. After the $6^{\text {th }}$ week, the smell of the oven dried sample was almost the same as that of the fresh with changes in its chemical properties.

\section{Fresh Frozen Sample}

\section{PROXIMATE RESULTS}

Fresh frozen Sample (FFS) is presented in Table 1. From results, at Wk 0 (zero time), the moisture, protein, lipid, ash contents were $61.30,16.72,7.89$ and 8.65 respectively. This does not really agree with the results of Daniel AmaAbasi and Anthony Ogar's work (2013) on fresh unfrozen samples with results of $51.7 \%, 21.5 \%, 17.2 \%$ and $7.76 \%$ respectively probably because of age and food availability (Solomon R.J., and Olushi A.R., 2018). During storage however, these values significantly decreased $(\mathrm{P} \leq 0.05)$ from Week 3 to Week 6 of storage due to handling and power supply interruption typical of Nigerian cold storage system. Notably, the fiber content was non-significant different from 3rd to 6th Wk.

Oven dried Sample (ODS) Stored at room temperature Oven dried sample (Week 0) had a high Protein content of $33.38 \%$ which decreased significantly $(\mathrm{p}<0.05)$ during storage from $32.64 \%$ (Week 3) to $29.19 \%$ (Week 6). The lipid content was $21.35 \%$ at Week 0 . However, the lipid content was significantly different from Week 3 to 6th Week. Ash content of $14.16 \%$ (Week 0) was not significantly different in the $3^{\text {rd }} \mathrm{Wk}$ but decreased significantly to $13.59 \%$ in Week 6.

Smoked Dried Sample (KSS) at room temperature

The protein content smoked fish stored at room temperature decreased during storage periods with results ranging from $32.83 \%$ (Week 0) to $25.17 \%$ (Wk 6) (Table $1)$. The lipid content at Week 0 was $26.72 \%$, with significant differences in values at the $6^{\text {th }}$ week. Ash content decreased significantly during storage and ranged from $10.23 \%$ (Week 0) to $13.77 \%$ (Week 6). *(Wk) means Weeks*

Table 2: Proximate analysis results

\begin{tabular}{|c|c|c|c|c|c|}
\hline $\begin{array}{l}\text { SAMPLES } \\
\text { Time: WEEK } 0\end{array}$ & MOISTURE\% & FAT $\%$ & PROTEIN \% & ASH $\%$ & $\mathrm{CHO} \%$ \\
\hline FFS & $61.30 \pm 0.565^{\mathrm{a}}$ & $7.89 \pm 0.014^{\circ}$ & $16.72 \pm 0.063^{\mathrm{b}}$ & $8.65 \pm 0.070^{\circ}$ & $5.43 \pm 0.445^{\circ}$ \\
\hline ODS & $5.44 \pm 0.608^{\circ}$ & $21.35 \pm 0.141^{\mathrm{b}}$ & $33.38 \pm 0.565^{\mathrm{a}}$ & $14.16 \pm 0.84^{\mathrm{a}}$ & $25.67 \pm 1.117^{\mathrm{a}}$ \\
\hline KSS & $10.29 \pm 0.219^{\mathrm{b}}$ & $26.72 \pm 0.417^{\mathrm{a}}$ & $32.83 \pm 0.395^{\mathrm{a}}$ & $10.23 \pm 0162^{b}$ & $19.91 \pm 1.195^{\mathrm{b}}$ \\
\hline \multicolumn{6}{|l|}{ WEEK 3} \\
\hline FFS & $61.44 \pm 0.007^{\mathrm{a}}$ & $6.80 \pm 0.106^{\circ}$ & $16.27 \pm 0.084^{\circ}$ & $8.14 \pm 0.035^{\circ}$ & $7.33 \pm 0.021^{\mathrm{b}}$ \\
\hline ODS & $9.22 \pm 0.049^{\circ}$ & $21.25 \pm 0.304^{\mathrm{b}}$ & $32.64 \pm 0.127^{\mathrm{a}}$ & $14.20 \pm 0.282^{\mathrm{a}}$ & $22.72 \pm 0.056^{\mathrm{a}}$ \\
\hline KSS & $12.74 \pm 0.190^{\mathrm{b}}$ & $26.31 \pm 0.827^{\mathrm{a}}$ & $29.38 \pm 0.028^{\mathrm{b}}$ & $10.14 \pm 0.226^{\mathrm{b}}$ & $21.42 \pm 1.216^{\mathrm{a}}$ \\
\hline \multicolumn{6}{|l|}{ WEEK 6} \\
\hline FFS & $64.53 \pm 0.664^{\mathrm{a}}$ & $6.29 \pm 0.063^{\circ}$ & $13.73 \pm 0.233^{\circ}$ & $8.57 \pm 0.813^{\mathrm{b}}$ & $6.86 \pm 0.318^{\circ}$ \\
\hline ODS & $11.66 \pm 0.304^{\circ}$ & $20.39 \pm 0.629^{b}$ & $29.19 \pm 0.205^{\mathrm{a}}$ & $13.59 \pm 0.494^{\mathrm{a}}$ & $25.15 \pm 0.233^{\mathrm{a}}$ \\
\hline KSS & $18.48 \pm 0.049^{\mathrm{b}}$ & $26.40 \pm 0.282^{\mathrm{a}}$ & $25.17 \pm 0.205^{\mathrm{b}}$ & $13.77 \pm 5.183^{\mathrm{a}}$ & $16.16 \pm 5.310^{\mathrm{b}}$ \\
\hline
\end{tabular}

FFS= Freshly Frozen Sample, ODS= Oven Dried Samples, KSS= Kiln Smoked Samples. *SD= Standard Deviation *Mean \pm $\mathrm{SD}$ are values of triplicate determination. ${ }^{*} \mathrm{SD}$ with different superscripts in the same column for each parameter are significantly $(\mathrm{P}<0.05)$ different

Figure 7 Moisture content $(\%)$

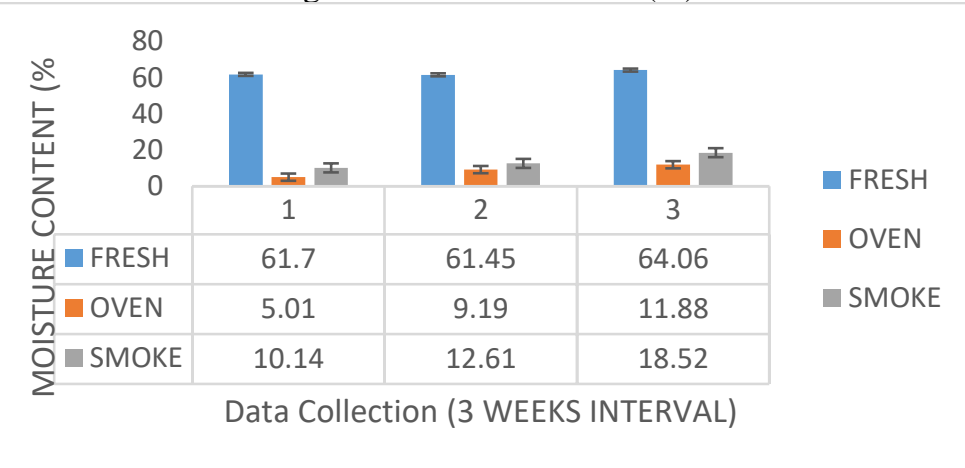

From the chart above, the moisture content of the freshly frozen sample contained more moisture compared to the other treatment. The moisture content of the oven dried sample was the lowest in terms of moisture. But with time, there was a slight increase in the moisture content indicating moisture absorption. 
Figure 8: Crude Protein content (\%)

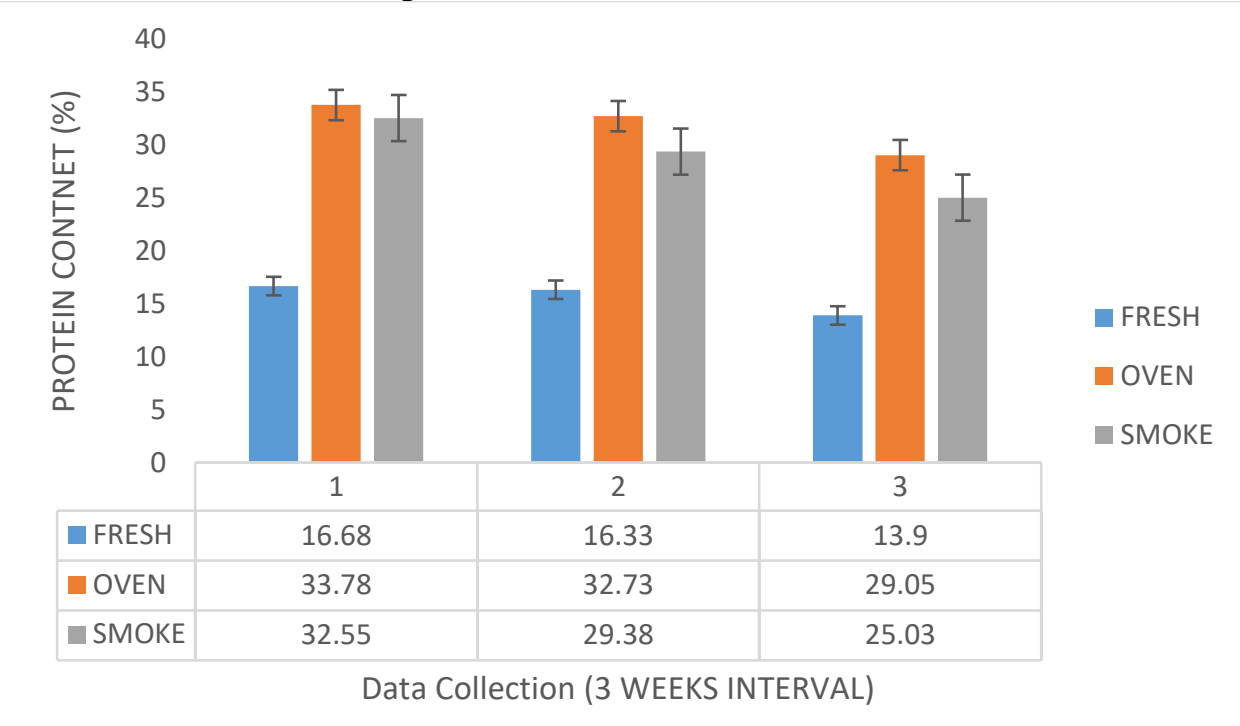

In figure 8, the protein concentration in oven dried sample had the highest value with slight reduction with time.

Figure 9 Ash $(\%)$

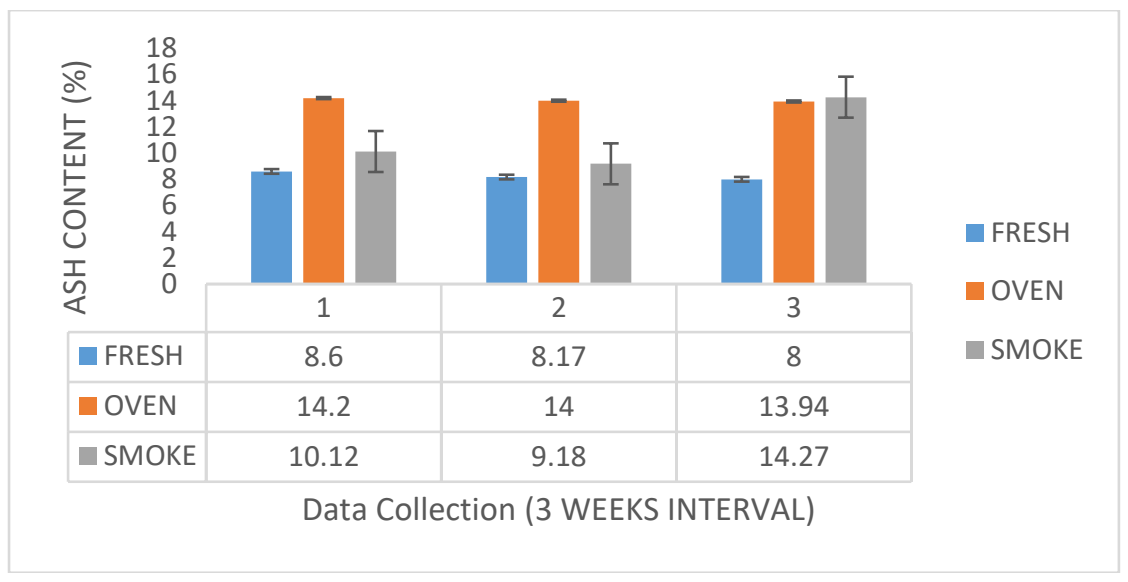

Oven dried sample has less moisture when compared to the other treatments. It maintained the ash content for the period of 6 weeks which means the minerals in it are well preserved but at the $6^{\text {th }}$ week, there was an increase in the mineral content of the smoked sample. The ash concentration in a freshly frozen sample was lower with slight reduction over time.

Figure 9 Carbohydrate $(\%)$

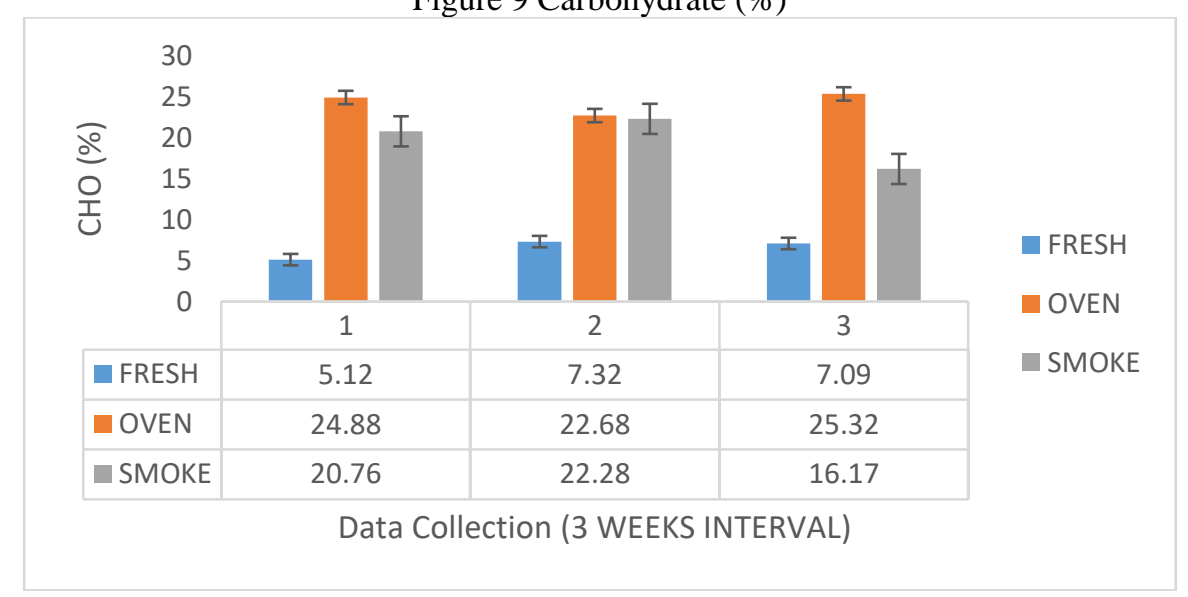


From the chart above, the carbohydrate content of the oven dried sample was highest while that of the freshly frozen sample was lowest. During the storage period, there was little significant change in the carbohydrate contents.

Figure 10 Lipid/ Fat

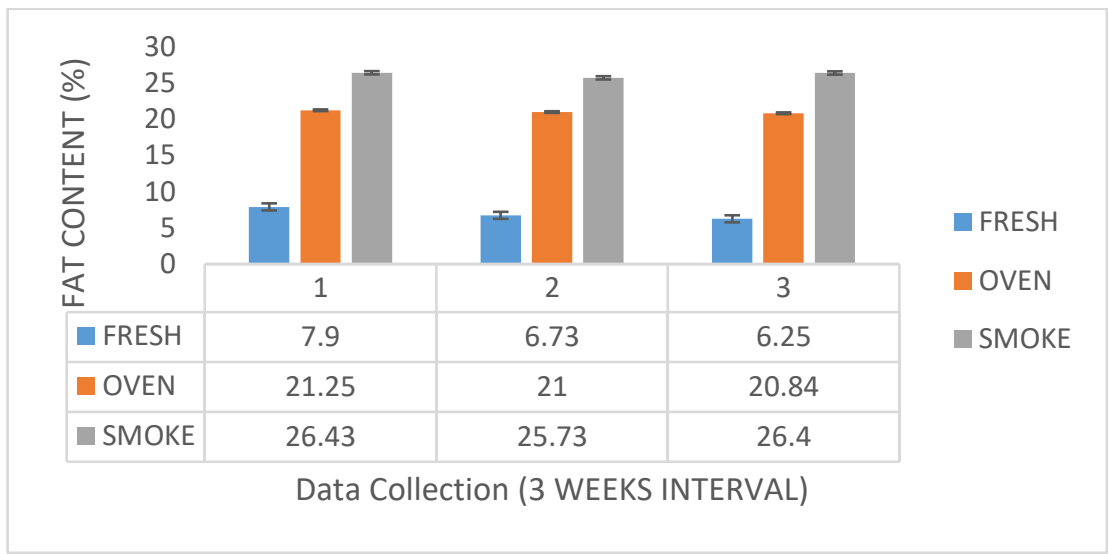

From the figure above, smoking helped in increasing the lipid concentration of the sample. The frozen sample has a lower concentration in the lipid content with a little difference in the lipid value.

\section{CONCLUSION AND RECOMMENDATION}

In this research study, smoking is the best method of preservation for Parachanna obscura. Generally, it was noticed that freezing reduces better, the rate of deterioration for a long period of time and prolongs the shelf life of fishes if stored under constant, uninterrupted power supply which calls for concern in the country.

Also, oven drying reduces the rate of deterioration for a short period of time before the fish begins to decay. Oven drying preserves the Nutritional value of Parachanna obscura for a short period of time, improves the protein level of Parachanna obscura better than other methods but it comes with disadvantages of high risk of rancidity which is harmful to the human health.

Smoking also reduces the rate of deterioration of Parachanna obscura but shorter compared to the other two preserving methods but it improves the level of free fatty acid, the cholesterol level and the flavor of the fish.

In terms of eating for health, smoking is preferred. Though, the protein level is a bit denatured, it is still within acceptable levels. It is better as it preserved the free fatty acids which contains omega 3 necessary for brain function and general wellbeing. This calls for further research on improvement in our oven drying method to reduce oil leakages from the fish flesh during drying as oil rancidity is dangerous to health.

\section{REFERENCES}

[1] Adeyeye S.A.O, (2016). Traditional fish processing in Nigeria: A critical review, Nutrition \& Food Science. DOI: 10.1108/NFS-112015-0148

[2] Allain, C.C, Poon, L. S., Chan C. S. G., Richmond W., Fu P. C. (1974). Clin. Chem., 20. 470-45. Revision: July 2013.

[3] Andrew Weil, M.D. (2008). Is fish Oil Bad for Low Density Lipoprotein,www.drweil.com

[4] AOAC ( Association of Official Analytical Chemist), official methods of analysis, $17^{\text {th }}$ Edition. (Ed. S. Williams), Arlinton, V.A. 2006,1125 p.

[5] Charupat Pakawatcha, Sunisa Siripongvutikorn and Worapong Usawakesmanee (2009). Effect of herb and spice pasters on the quality changes in minced salmon flesh waste during chilled storage. Asian Journal of Food and Agro-Industry. 2(4), 481-492.

[6] Cox H.E and Pearson D. (1962): The Chemical Analysis of Foods Chemical Publishing Co Inc New York p420.

[7] Daniel Ama-Abasi and Anthony Ogar (2013).Proximate analysis of snakehead fish, Parachannaobscura, (Gunther 1861) of the Cross river, Nigeria.Journal of fisheries and aquatic science, vol.8 (1), pp 295-298.

[8] Eyo A.A.(2001) Fish Processing Technology in the Tropics, University of Ilorin Press. 403pp.

[9] Felix Akinwunmi Effects of Smoking and Freezing on the Nutritive Value of African Mud Catfish, ClariasgariepinusBurchell, 1822, Journal of Agricultural Science, Vol 6, No 11 DOI: 10.5539/jas. V6n11p143

[10] Gornik, S.G., Albalat, A., Macpherson H., Birkbeck H., Neil D.M. (2011) Effects of temperature on the bacterial load and microbial composition in Norway lobster tail meat during storage, June 2011. DOI: 10.1111/). 1365-2672.2011.05081.

[11] Guy Apollinaire Mensah, Kpogue Diane Nathalie Senami, Emile D. Fiogbe, (2012) A review of biology, ecology and prospect for aquaculture of Parachannaobscura. Reviews in fish biology and fisheries 23(1) DOI: 10.1007/s11160-012-9281-7

[12] Jinadasa B.K.K.K.(2014). Determination of quality of marine fishes based on Total Volatile Base Nitrogen test (TVB-N), Nat Sci. 12(5): 106-111). (ISSN: 1545-0740)

[13] John Alaba Victor Famurewa, Ogheneughwe Godwin Akise and TemitopeOgunbodede (2017) Effect of storage methods on the nutritional quality of African Catfish Clariasgariepinus(Burchell, 1822) Vol. 11 Academic journals pp.223-233, July 2017

[14] Kigbu A.A., Imgbian T.D., and Yakubu M.M. (2014). Unconventional cultivable freshwater fish species: a potential tool for increased aquaculture production in Nigeria. Global journal of fishes and aquaculture, Vol 2 (3),pp152-157

[15] Olanrewaju AN, Ajani EK and Kareem OK, Physio-chemical Status of Eleyele Reservoir, Ibadan, Nigeria. J Aquac Res Development 2017, 8:9, DOI: 10.4172/2155-9546.1000512

[16] Oyekanmi F.B. and Olutimehin I.O., (2019). Chemical composition of some conventional fishes obtained in Asejire dam, Egbeda local government of Oyo state, Nigeria. Global journal of agricultural research, Vol. 7 No 2, pp37-51

[17] SerkanKoral, BekirTufan, Nadir Bascinar and SevimKose, Quality Changes and Shelf Life of Cultured and Wild HotSmoked Mediterranean Horse Markerel (Trachurus mediterraneus $)$ at Refrigerated $\left(4 \pm 1^{\circ} \mathrm{C}\right)$ Conditions, Journal of Aquatic Food Product Technology, DOI:1080/10498850.2015.1008715 
[18] Shelly Najar (2012). Health Effects of Rancid fat, Nutrition Nuts and Bolts, extracted from https:// nutritionnutsandbolts.com/2012/08/01/rancid-fat/

[19] Solomon R.J., and Olushi A.R.(2018) Proximate analysis and nutritional value of African catfish (Clarias gariepinus) fed with local (Telferia occidentales and Moringa oleifera) and industrial feed (Coppens). Journal of fisheries and livestock production vol.6:2: doi:10.4172/2332-2608.1000267

[20] Tawari C. and. Abowei J.F.N, (2011) Traditional Fish Handling and Preservation in Nigeria, Asian Journal of Agricultural Sci 3(6): 427-436, 2011. (ISSN: 2041-3890) 